\title{
Tomasz Tomasik
}

Instytut Polonistyki

Akademia Pomorska w Słupsku

e-mail: tomasz.tomasik@apsl.edu.pl

ORCID: 0000-0001-8778-0406

\section{"O miłości, bez erotyzmu". Lektura filologiczna Podwójnego oddechu Zbigniewa Herberta}

dyskurs miłosny jest dzisiaj nadzwyczaj samotny

Roland Barthes ${ }^{1}$

Publikacja juwenilnych erotyków oraz listów Zbigniewa Herberta zadedykowanych Halinie Misiołek i do niej zaadresowanych wywołała wielopoziomowy skandal - edytorski, prawny, obyczajowy, historycznoliteracki. Nałożyło się tu na siebie kilka różnogatunkowych spraw: bezprzykładna redaktorska fuszerka, naruszenie praw autorskich spadkobierczyń, spór między tandemem żony i siostry poety $\mathrm{z}$ jednej strony a wydawcami (i samą „Muzą") z drugiej oraz ocena artystycznego poziomu udostępnionych wierszy.

Kwestie prawno-obyczajowe pozostawmy na boku, z literaturoznawczego punktu widzenia ciekawsze wydaje się bowiem pytanie o usytuowanie obu „inkryminowanych” tomików zarówno w porządku biografii, jak i twórczości poety. Jak je potraktować? „Ścisła dyskrecja, kurtyna milczenia, zasłona miłosierdzia spuszczona na te pierwsze porywy geniuszu?" - przed takim dylematem stanął jeden z pierwszych krytyków Podwójnego oddechu, Józef Fert. Ostatecznie jednak zawyrokował, że "tomik ten - tak nieudolnie i wręcz niechlujnie wydany - pozwala wejrzeć w głąb początków twórczo-

\footnotetext{
${ }^{1}$ R. Barthes, Fragmenty dyskursu miłosnego, przeł. M. Bieńczyk, Warszawa 1999, s. 37.
} 
ści Herberta, początków w zasadzie nieczytelnych w jego dojrzałych tomach wydawanych od 1956 roku" 2 .

\section{„miłość, pierwsza, męska”}

„Niedokończona” czy też „nieskończona” miłość [UR, s. 37]³, właśnie dzięki listom i wierszom całkiem dobrze udokumentowana, nie była przelotnym tylko i krótkotrwałym love affair. Początek tej znajomości - jak wspomina Misiołek - miał miejsce w Sopocie w roku 1947, a może nawet rok wcześniej. Natomiast rozstanie z inicjatywy Herberta nastąpiło w roku $1957^{4}$. Były to $\mathrm{w}$ życiu poety in statu nascendi lata trudne i zarazem przełomowe, „okres prób i wahań" 5 . Pomieszkiwał wtedy w sopockim domu rodziców, ale często zmieniał miejsca pobytu. Na uniwersytecie $\mathrm{w}$ Toruniu najpierw kontynuował studia prawnicze i na tym kierunku uzyskał tytuł magistra, a potem od roku 1949 uczęszczał na zajęcia z filozofii; tu spotkał swojego mistrza Henryka Elzenberga. W 1953 roku przeniósł się do Warszawy, gdzie próbował dokończyć studia filozoficzne. Coraz bardziej utwierdzał się jednak w przekonaniu, że jego życiowym powołaniem jest nie filozofia, tylko literatura. Twórczość pisarską zainicjował w 1948 roku, publikując w szczecińskim „Tygodniku Wybrzeże” cykl felietonów Poetyka dla laików. W okresie socrealistycznego dyktatu w kulturze pisywał recenzje, eseje i wiersze do czasopism przede wszystkim katolickich: krakowskiego „Tygodnika Powszechnego", PAX-owskich „Dziś i Jutro" i „Słowa Powszechnego”, jezuickiego „Przeglądu Powszechnego". Od roku 1950 zaczęły się ukazywać jego debiutanckie utwory poetyckie; ich liczniejszy wybór został zaprezentowany w almanachu ...każdej chwili wybierać muszę z roku 1954 i w tzw. prapremierze pięciu poetów zamieszczonej na łamach „Życia Literackiego" pod koniec 1955 roku. W tym okresie prowadził korespondencję z licznymi adresatami: oprócz Misiołek (od 1950), także z Jerzym Turowiczem (od 1947), Jerzym Zawieyskim (od 1949), Tadeuszem Chrzanowskim (od 1950), Henrykiem Elzenbergiem (od 1951). Andrzej Lam uznał, mając w tym sporo racji, że „Herbert ukształtował się w swoich głównych rysach jako poeta

2 J. Fert, Hala Pana Cogito czyli wszystko na sprzedaż, „Ethos” 2000, nr 4, s. 164, 170.

3 Cytuję za: Z. Herbert, Utwory rozproszone. (Rekonesans), wybór i oprac. edytorskie R. Krynicki, Kraków 2010. W odniesieniu do tego wydania stosuję skrót UR z podaniem numeru strony.

4 J. Siedlecka, Pan od poezji. O Zbigniewie Herbercie, Warszawa 2002, s. 150 i 161.

5 Z. Herbert, H. Elzenberg, Korespondencja, oprac. B. Toruńczyk, Warszawa 2002, s. 12. 
w latach 1950-1954"6. A ponieważ z wierszówek trudno było wyżyć (kontynuował równocześnie swoje „wariackie studia"7), musiał też w tym okresie szukać dla siebie bardziej stałego zatrudnienia. W żadnej pracy nie zagrzał jednak miejsca na dłużej. I tak oto, będąc mężczyzną w wieku lat 25-30 wciąż zmagał się z brakiem życiowej stabilizacji.

Do tych gorączkowych poszukiwań artystycznych, intelektualnych i religijnych (a przy okazji też towarzyskich) - i tak już niełatwych do pogodzenia ze sobą - dochodzi jeszcze związek uczuciowy z "Daleką i Czystą" (określenia z dedykacji Podwójnego oddechu) Halą, starszą o dziewięć lat mężatką, matką dwóch córek. Afera miłosna doprowadziła zresztą do rozpadu małżeństwa Misiołków. Wszystko wskazuje jednak na to, że poeta traktował ten związek poważnie, choć zarazem dość osobliwie. Miała to być miłość "czysta", ale w praktyce okazała się przyczyną nieustannych wyrzutów sumienia, samoudręczeń i dość zawikłanej gry emocji.

Znamienne, że Herbert we własną historię miłosną wtajemniczał (choć w różnym stopniu) swoich ówczesnych korespondentów. Ewidentnie szukał u zaufanych osób porady i moralnego wsparcia. Najpierw zwrócił się do Jerzego Zawieyskiego, którego nieco później uznał za „Poetę Spraw Trudnych”. Preludium do tych wyznań stanowił list z 8 kwietnia 1950 roku, w którym poeta relacjonował "pierwszemu spowiednikowi” swoje itinerarium mentes ad Deum (drogę umysłu do Boga). Najpierw tłumaczył, że jego "wariackie studia" były tak naprawdę przejawem "niepokoju religijnego" ${ }^{8}$. Następnie opisał zmagania z "groźną pokusą subiektywizmu" - zreflektował się mianowicie, że praktykowana przez niego obsesyjna obserwacja własnych przeżyć to nic innego tylko „zachłanna, pogańska ciekawość samego siebie, ale ta wyzwolona spod władzy moralności i myśli, puszczona samopas” ${ }^{9}$. „Eksperyment" okazał się zatem "żałosny i niebezpieczny". "Zatraciłem zupełnie - wyznaje poeta - świeżość przeżyć, zatraciłem szczerość. [...] I utraciłem miłość, to co najważniejsze przecież. Za to była jakaś mania ciągłych kreacji" ${ }^{10}$. Introspekcja uświadomiła deficyty uczuć, ale pozwoliła jednocześnie podjąć zasadnicze zobowiązanie: „Trzeba się zaangażować w miłość całym sobą. To jest jedyna droga do Najwyższego, o którym Św. Augustyn

6 A. Lam, Zbigniew Herbert przed debiutem ksiażkowym, w: Twórczość Zbigniewa Herberta, red. M. Woźniak-Łabieniec, J. Wiśniewski, Kraków 2001, s. 26.

7 Z. Herbert, J. Zawieyski, Korespondencja 1949-1967, oprac. P. Kądziela, Warszawa 2002, s. 33.

8 Tamże.

9 Tamże, s. 34.

10 Tamże. 
mówi ślicznie "o moja słodyczy»"11. Rzeczywiście, to jedyna droga, ale rozumiana na sposób chrześcijański - nie jako zmysłowy Eros, tylko jako duchowa Agape. Autor skierowanych do Boga Wyznań wyrażał się w tej sprawie jednoznacznie: „Mniej kocha ten, kto oprócz Ciebie kocha coś innego jeszcze, co nie ze względu na Ciebie miłuje" ${ }^{\prime 2}$. I oto pół roku później w liście z 4 października 1950 roku zwierza się Herbert duchowemu powiernikowi, ale już wprost, ze swoich miłosnych perypetii:

Więc jest to, krótko mówiąc, miłość, pierwsza, męska. Początek był jeszcze bardzo idealistyczny, bardzo zielony. Pragnąłem mieć wpływ na sferę intelektualną, duchową kochanej, nieszczęśliwej istoty, pomagać, walczyć razem $\mathrm{z}$ nią, zdobywać prawdę, Boga, radość, wiarę w sens życia. Wkrótce jednak wszystko na przekór wzajemnym ślubom czystości zaczęło się stawać bardzo niebezpieczne, bardzo zmysłowe, bardzo cielesne. Jestem starym bykiem, mam za sobą niejedno doświadczenie, ale $\mathrm{w}$ tym wypadku, dlatego właśnie, że to była miłość prawdziwa, a to znaczy bezinteresowna i czysta - nie mogłem, nie chciałem zgodzić się na ten brutalny schemat, jaki narzuca życie ${ }^{13}$.

Nie ma powodów, by wątpić w szczerość powyższego wyznania, niemniej jednak warto zwrócić uwagę na jego „retoryczność”, zacierającą wrażenie egzaltacji i pozwalającą doszukiwać się strategii autokreacyjnych. Wewnętrzny konflikt, z którym zmaga się poeta, został zdiagnozowany i nazwany bardzo precyzyjnie $\mathrm{w}$ nomenklaturze, co nie powinno dziwić, właściwie augustyńskiej: „,kochana istota” i Bóg, sfera intelektualna i sfera zmysłowa, duchowe i cielesne, idealizm i brutalizm, a w tym wszystkim pragnienie miłości prawdziwej, bezinteresownej i czystej. "Brutalny schemat” polegał na tym, że zmysłowo-cielesny Eros zaczął dominować nad intelektualno-duchową Agape. Zamiast sublimacji nastąpiła wulgaryzacja. Taka sytuacja oznacza oczywiście wewnętrzne zmaganie - agon:

Była to dla mnie (a właściwie jest) - próba człowieczeństwa, konkretna, angażująca mnie całego, trudna, czasem rozpaczliwa i beznadziejna. Była to walka pełna upadków i buntów, i grzechu, to znowu pogodzenia i ufności. $\mathrm{W}$ takich wypadkach najprostszym rozwiązaniem jest samobójstwo albo ucieczka. Oba rozwiązania, pozorne rozwiązania, są wstrętne. Kobieta, którą kocham, jest w sakramentalnym związku, który musi być uszanowany ${ }^{14}$.

\footnotetext{
11 Tamże, s. 35.

12 Z. Herbert, Węzet gordyjski oraz inne pisma rozproszone 1948-1998, zebrał i oprac. P. Kądziela, Warszawa 2001, s. 7-8).

13 Z. Herbert, J. Zawieyski, Korespondencja, s. 39.

14 Tamże, s. 39-40.
} 
Sytuacja Herberta przypominała moralny dylemat znany z autobiografii św. Augustyna: „W owych też latach żyłem z kobietą nie związaną ze mną prawnym małżeństwem, na którą natrafiła moja nie kierująca się roztropnością namiętność" 15 . Decyzje zapadły jednak inne: przyszły biskup Hippony oddalił po prostu nieznaną $\mathrm{z}$ imienia kochankę, poeta $\mathrm{w}$ tym akurat momencie postąpił inaczej:

A zatem wyrzeczenia. Ale nie mogę wyrzec się miłości, przez którą żyję, tylko tego, co w niej grzeszne. A zatem dramat trwa. Widzę, że jest to jedna $\mathrm{z}$ dróg do Boga. Świat wydaje mi się inny, głębszy, życie trudniejsze. Ale wdzięczny jestem Bogu za to doświadczenie. I wierzę, że zaprowadzi ono nas do prawdy. "Nas", bo już nie tylko za swój los jestem odpowiedzialny ${ }^{16}$.

Mogłoby się wydawać, że miłosne perypetie i towarzyszące im moralne dylematy dynamizowały i pogłębiały życie duchowe poety. Dramat jednak trwał i stawał się coraz większym obciążeniem: „Jest mi po prostu bardzo ciężko. Czasami wydaje mi się, że nie udźwignę mojej miłości. Modlę się tylko na oślep bardzo zmęczony walką o drugiego Człowieka. Nie ma rzeczy, której bym dla niego nie poświęcił" - pisał Herbert 1 marca 1951 roku w liście do Zawieyskiego ${ }^{17}$. W kolejnych zdaniach, przeprowadzając „ścisły i zimny rachunek sumienia", przyznaje jednak, że nie wszystko potrafi poświęcić dla „swojej miłości":

Po krętych drogach przez grzech i upadki coraz nieuchronniej idę do Boga. Mobilizuję siły intelektualne, buduję filozofię wyrzeczenia, subtelny system moralny - $\mathrm{i}$ to jest jakaś wielka niesprawiedliwość. Bo tamten, drugi człowiek, czeka na prostą, bezpośrednią miłość. I ma prawo żądać, abym nie używał jego uczucia do budowania mojej spokojnej i moralnej samotności. I ma prawo żądać, abym odpłacał mu czymś więcej niż wierszami. (Nie ma chyba bardziej brutalnej formy eksploatowania życia niż tzw. poezja miłosna) ${ }^{18}$.

Dręczący poetę wyrzut sumienia dotyczył zatem uświadomionej, ale też praktycznie niemożliwej $w$ jego przypadku do uniknięcia marginalizacji „drugiego człowieka” - „prosta, bezpośrednia miłość” ustępuje miejsca tworom intelektu: „filozofii wyrzeczenia" $i$,subtelnemu systemowi moralnemu”, dorzućmy do tego jeszcze religijną psychomachię. Można powiedzieć: cogito wyrzeka się amo.

\footnotetext{
15 Św. Augustyn, Wyznania, przeł., opatrzył posłowiem i kalendarium Z. Kubiak, Warszawa 1987, s. 63.

16 Z. Herbert, J. Zawieyski, Korespondencja, s. 40.

17 Tamże, s. 47.

18 Tamże, s. 48.
} 


\section{„brutalna forma eksploatowania życia”}

$\mathrm{Na}$ „brutalną formę eksploatowania życia” zdecydował się Herbert, zanim zdobył się na powyższe wyznania. Poinformował o tym Zawieyskiego 4 października 1950 roku: „Napisałem cykl wierszy o miłości, bez erotyzmu" ${ }^{\prime 1}$. W liście zamieścił fragment utworu Nasza miłość. Mniej więcej w tym samym czasie o pracy nad tomikiem Podwójny oddech dowiedział się także Tadeusz Chrzanowski, który w listopadzie 1950 odpowiedział na wcześniejszy, niezachowany list: „Z odrobiną zazdrości przeczytałem, że Pan pisze «pod Staffa i Lieberta» dla Pani, która takowych lubi" 20. Wzmianka pojawiła się również w liście z 13 grudnia 1950 roku do Jerzego Turowicza: „W tych dniach kończę drugi tom wierszy, których, jako że zbyt osobiste, nie przeznaczam do druku" ${ }^{21}$.

W dedykacji donosił Herbert, że wiersze, które weszły do Podwójnego oddechu, powstawały w okresie od sierpnia do grudnia 1950 roku, chociaż niektóre spośród nich zostały napisane nieco wcześniej. Edytorsko poprawiony tomik, zawarty w pierwszym wydaniu Utworów rozproszonych, ujawnia swoją cykliczną formę, zatraconą zupełnie w publikacji pirackiej. Nie ma wątpliwości, że jest to skomponowany z rozmysłem zbiór utworów poetyckich, składających się na "pamiętnik niedokończonej” / "nieskończonej miłości”. Warto go przeczytać sine ira et studio, powstrzymując się od, być może nazbyt pochopnej, oceny estetycznej, bo są te poetyckie teksty jednak czymś więcej niż tylko świadectwem „młodzieńczej” egzaltacji. Ważna jest choćby kwestia inspiracji - czy rzeczywiście zostały napisane "pod Staffa i Lieberta"? Ciekawe może się też okazać sprawdzenie, jak mają się do siebie te dwie dyspozycje: amo i cogito. I co to znaczy, że utwory są "zbyt osobiste"?

Wiersze zostały pogrupowane $\mathrm{w}$ trzech odrębnych, ponumerowanych częściach, a każdą z nich opatrzono mottem. Zbiorek otwiera dedykacja i skierowana do "Najmilszej” przedmowa, w której bodaj najbardziej wybija się obawa poety przed tym, czy zapisane, "liche" słowa będą w stanie wyrazić jego uczucia i czy adresatka doszuka się w nich siły. „Ale jakie słowo wyraża rozłąkę i bliskość, wyciągnięte ręce i Twój wzrok, który czuję na sobie" [UR, s. 37] - pyta poeta, trochę chyba jednak ujawniając swoją literacką intencję. Kryje się w tej wypowiedzi zapowiedź dominujących w nim emocji: doświadczenie rozłąki i pragnienie bliskości.

\footnotetext{
19 Tamże, s. 40.

20 Z. Herbert, T. Chrzanowski, "Mój bliźni, mój bracie”. Zbigniew Herbert - Tadeusz Chrzanowski: listy 1950-1998, oprac. Z. Baran, Kraków 2016, s. 12.

21 Z. Herbert, J. Turowicz, Korespondencja, oprac. T. Fiałkowski, Kraków 2005, s. 15.
} 
Dokładnie tego dotyczy pierwsza część tomiku: zarówno opatrująca go lemma "Jeszcze jej nie ma" [UR, s. 39], jak i składające się na niego poetyckie teksty. Można przyjąć, że zwrot "nie ma” oraz wiersz Samotność wskazują na rozłąkę, zwrot ,jeszcze” oraz wiersz Czułość - na nadzieję bliskości.

\section{Figury dyskursu miłosnego: samotność}

W liryku Samotność dochodzi do wyraźnego, zaznaczonego także graficznym rozkładem strof, przeciwstawienia dwóch przestrzeni: zewnętrznej (kałuże, latarnia, kamienny chodnik, gwiaździste niebo) oraz wewnętrznej („[p]iękne [...] wnętrza mieszkań" - UR, s. 41). Persona wypowiadająca się $\mathrm{w}$ tym utworze, przemierzająca samotnie miejskie ulice, może jedynie pomarzyć o niedostępnej mieszczańskiej Gemütlichkeit, ale potrafi ją sobie wyobrazić w sposób bardzo konkretny i zmysłowy:

Piękne są wnętrza mieszkań
stajnie pachnące mahoniem
Obite ciepłym kolorem
słodkich mandarynek
Na środku stół okrągły
trafiony flakonem kwiatów
Przed lustrem naga żona
układa sypkie włosy
można je w nocy rozplatać

[UR, s. 41]

Ta ostatnia strofa przypomina scenę z Białej magii Baczyńskiego: „Stojąc przed lustrem ciszy / Barbara z rękami u włosów / nalewa w szklane ciało / srebrne kropelki głosu" ${ }^{22}$. Podobieństwo tych fragmentów dotyczy także metrum - w obu zastosowana została toniczna trójzestrojowość. Możliwe jednak, że w wierszu Herberta pobrzmiewają echem dwa inne, właściwie identycznie zatytułowane, utwory: Einsamkeit Rilkego i Samotność Staffa ${ }^{23}$. Obaj autorzy - czemu przyjrzę się bliżej w innych miejscach - odcisnęli swoje

22 K.K. Baczyński, Utwory zebrane, t. I, oprac. A. Kmita-Piorunowa i K. Wyka, Kraków 1970, s. 176.

23 Wiersz Rilkego pochodzi z tomu Księga obrazów (1902-1906) [R. M. Rilke, Poezje, wybrał, przeł. i posłowiem opatrzył M. Jastrun, Kraków 1987, s. 46-47], wiersz Staffa z tomu Martwa pogoda (1946) [L. Staff, Wiersze zebrane, t. 5, red. M. Szypowska, Warszawa 1955, s. 274]. 
poetyckie signum na Podwójnym oddechu. W tych trzech wierszach tytułowy stan emocjonalny został skojarzony z określoną aurą: u Rilkego - „Die Einsamkeit ist wie ein Regen” („Samotność jest jak deszcz" - przekład Mieczysława Jastruna), u Staffa - „Którędy iść mi w dzień ten, pełen chmur, wichury”, u Herberta natomiast - „Krok mój płoszy kałuże / liście zwiędłego nieba”, i nieco dalej - „kroki płoszą kałuże / wzruszają kamienny chodnik" [UR, s. 41].

Pisanie „pod Staffa” ujawnia się jeszcze w dwóch fragmentach wiersza. Najbardziej ostentacyjnie w następującym dystychu: „Przewlekam przeciągłą samotność / przez ucho igielne latarni" [UR, s. 41]. Ewangeliczna hiperbola "ucho igielne" to oczywiście nawiązanie do tytułu wydanego w 1927 roku zbioru wierszy Staffa, ważnego z powodu wyrażonych w nim na sposób osobisty doświadczeń religijnych. Swego czasu znakomicie uchwycił to Jerzy Liebert, który $\mathrm{w}$ recenzji tego tomu, analizując poezję dwudziestolecia międzywojennego, zwrócił uwagę na zarysowujące się w tamtym okresie „dwa wyjścia”, , „dwie drogi przebicia się ku rzeczywistości” z młodopolskiego jeszcze „kręgu osamotnienia” 24. Pierwszą drogą podążył Jan Kasprowicz w Księdze ubogich, drugą właśnie Staff w Uchu igielnym. Tym dwóm poetyckim eksploracjom odpowiadają dwa typy postaw religijnych. Zdaniem recenzenta tytułowe „ucho igielne" należy rozumieć jako „wyjście na Boga”; ten gest świadczy o tym, że autor Snów o potędze "poprzez szukanie rzeczywistości własnego życia duchowego zaślubiał Boga w tragicznej samotności - antypodzie romantycznego osamotnienia". W wierszu Herberta odnajdujemy frazy brzmiące co prawda ewangelicznie: „Nie mogę znaleźć królestwa / błogosławieni którzy" [UR, s. 41], ale odnoszą się one raczej do niedostępnego błogostanu w "pięknym wnętrzu mieszkania”. Łatwiej jest wielbłądowi przejść przez ucho igielne, niż poecie wejść do królestwa mieszczańskiej szczęśliwości. W epilogu okazuje się jednak, że doświadczenie sacrum staje się możliwe w miejskiej przestrzeni ulicy, co na chwilę przynajmniej pozwala wyrwać się ze stanu samotności:

\section{I tylko Syriusz sprzyja uśmiechem mnie pozdrawia to mój jedyny przyjaciel Gwiazda.}

[UR, s. 42]

24 J. Liebert, Pisma zebrane 1. Poezja - proza, zebrał, oprac. i wstępem opatrzył S. Frankiewicz, Warszawa 1976, s. 550. 
W tym fragmencie pojawia się kolejny motyw Staffowski i zarazem Rilkeański - "czciciel gwiazd", jak określał siebie samego w jednej z autocharakterystyk autor Ucha igielnego ${ }^{25}$. A w poezji zdobywał się na takie wyznania: „W obliczu gwiazd milknących dusza moja klęka" (Spowiedź) ${ }^{26}$ i sięgał po takie apostrofy: „O, siostry-gwiazdy, nie dalsze / Niż człowiek jest człowiekowi" (Noc księżycowa) 27. W jego twórczości obiekty astralne pełniły rolę znaków wskazujących na istnienie Transcendencji ${ }^{28}$. U Rilkego podobnie, jak chociażby w znanym wierszu Do Anioła, w którym poeta zwraca się do tytułowej istoty nadprzyrodzonej z modlitewną prośbą: „Leuchte, leuchte! Mach mich angeschauter / bei den Sternen" - „Swieć mi, świeć mi, uczyń mnie widocznym / dla gwiazd" (przekład M. Jastruna) ${ }^{29}$. Przywołajmy też dwuwiersz z erotyku Ofiara: „Nur dein Lächeln stert wie lauter Sterne / über dir und bald auch über mir" - „Tylko uśmiech twój jak gwiazda się zapala / ponad tobą i potem nade mną" ${ }^{30}$. U każdego $\mathrm{z}$ tych trzech poetów: Rilkego, Staffa, Herberta gwiazdy - przestrzennie odległe, ale emocjonalnie bliskie wskazują na nadrzędny porządek metafizyczny. A samotność, choć dojmująca, to jednocześnie warunkuje doznania duchowe, umożliwia doświadczenie sakralności świata.

\section{Figury dyskursu miłosnego: czułość}

Drugi wiersz z pierwszej części cyklu wyraża pragnienie zmysłowej bliskości. Jego tytuł, Czułość, wskazuje na słowo, które krąży w obiegu całej twórczości Herberta. Zresztą charakteryzuje ono dobrze także postawę filozoficzno-poetycką autorów, którzy zostali już przywołani: Rilkego i Staffa, a także Lieberta, któremu przyjdzie jeszcze poświęcić chwilę uwagi. Mateusz Antoniuk doszukiwał się nawet „tropu czułości” w spuściźnie poetyckiej Herberta. Skrupulatna analiza powyższego wiersza doprowadziła badacza do odkrycia trzech obecnych w nim „rejestrów znaczeniowych” pojęcia "czułość": 1) jako serdeczności, „która zdaje się eskalować [...] w hipertrofię

\footnotetext{
${ }^{25}$ W wierszu Przedśpiew z tomu Gałą́ kwitnąca (1908) [L. Staff, Wiersze zebrane, t. 2, red. M. Szypowska, Warszawa 1955, s. 7].

26 L. Staff, Wiersze zebrane, t. 1, red. M. Szypowska, Warszawa 1955, s. 125.

27 L. Staff, Wiersze zebrane, t. 5, red. M. Szypowska, Warszawa 1955, s. 207.

${ }_{28}$ M. Jasińska-Wojtkowska, Sacrum w poezji Leopolda Staffa, w: Religijne tradycje literatury polskiej, t. 1: Polska liryka religijna, red. S. Sawicki, P. Nowaczyński, Lublin 1983, s. 379.

29 R. M. Rilke, Poezje, s. 310-311.

30 Tamże, s. 74-75.
} 
emocji", 2) jako cechy ludzkiej kondycji (człowiek czuły), 3) jako wyczulenia na jakości zmysłowe i duchowe ${ }^{31}$. Niewątpliwie czułość oznacza w słowniku Herberta coś więcej niż tylko emocjonalny sentymentalizm. Ja poetyckie tego utworu zostało umiejscowione w "kamiennym mieście”, czyli podobnie jak w liryku Samotność:

Płynę ulicą wyschłą jak gardło zmarłego proroka pozdrawiając mijanych do których przyjaźnie wyciągam oczy

$$
\text { [UR, s. 43] }
$$

Miejska ulica wydaje się nieprzyjazna - kamienna, wyschła, wymarła. Tej nieprzychylnej zewnętrznej przestrzeni podmiot tego wiersza zdaje się przeciwstawiać wewnętrzną przestrzeń swoich uczuć, deklaruje pragnienie przyjaznego, życzliwego, serdecznego spotkania z mijanymi ludźmi. Nawiązanie relacji przyjacielskich okazuje się jednak niemożliwe, bo przechodnie znikają za zakrętem ulicy. Czułość jest u Herberta doświadczeniem zmysłowym, wyraża się poprzez spojrzenie i dotyk, korzysta z pomocy oczu i dłoni ${ }^{32}$. Fraza "przyjaźnie wyciągam / oczy” sugeruje wręcz istnienie metonimicznego związku między tymi dwoma zmysłami ${ }^{33}$. Wychodząc z takiego założenia, dałoby się wytłumaczyć zamykającą wiersz peryfrazę „imienia czułości": „Dotkliwa szyja wiolonczeli / strumyczek włosów na policzku” [UR, s. 44]. Zarówno kształt instrumentu, jak i podpatrzony detal (kobiecej?) twarzy to obrazy bardzo konkretne w swej wizualności. Niejednoznaczny epitet „dotkliwa” należy niewątpliwie kojarzyć z doznaniem taktylnym ta, którą się dotyka, ale też, która prowokuje dotyk, a także, która jest podatna na dotyk.

Samotność i czułość stanowią emocjonalną uwerturę dla historii miłosnej opowiadanej w Podwójnym oddechu.

31 M. Antoniuk, Otwieranie głosu. Studium o wczesnej twórczości Zbigniewa Herberta (do 1957 roku), Kraków 2009, s. 402-403.

32 W mini prozie H.E.O. na pytanie Eurydyki „Co to jest czułość?” Hermes odpowiada „To radość dotyku” [Z. Herbert, Król mrówek. Prywatna mitologia, oprac. R. Krynicki, Kraków 2008, s. 11].

33 Jeszcze bardziej ewidentne jest to w wierszu o takim samym tytule Czułość zamieszczonym w Epilogu burzy, gdzie „czułości” zaleca się: „powinnaś spać we wnętrzu dłoni na dnie oka” [Z. Herbert, Wiersze zebrane, oprac. edytorskie R. Krynicki, Kraków 2011, s. 699]. 


\section{Figury dyskursu miłosnego: spacer}

Drugą część cyklu otwiera nieznacznie zniekształcony dystych z wiersza Lieberta Zagadka: „Ramieniem Ciebie garnę, skrzydłem dotykam nieba / Lecz ty nie jesteś niebem, wiem o tym i tak trzeba" ${ }^{34}$. Cytat pochodzi z erotyku, a tytułowa „zagadka” dotyczy, opisywanych w poetyce niemalże barokowej, paradoksów miłości: „Strumieniem chłodnym płyniesz przez głębie serca mego / A serce żarem płonie i pali się, dlaczego?". Dość konwencjonalne metafory. W samym zaś motcie pobrzmiewają echa schrystianizowanego platonizmu: miłość do kobiety pozwala mężczyźnie „dotknąć nieba”, ale kobieta nie jest „niebem” - Eros podprowadza jedynie do przedproży Agape. I to przekonanie: "tak trzeba”.

Z przytaczanego już tutaj listu Chrzanowskiego wiemy, że Herbert pisał Podwójny oddech także „pod Lieberta” i że był to ulubiony poeta Misiołek. Autor Guseł funkcjonował trochę na zasadzie miłosnego podarunku. W liście z 27 lutego 1951 roku Herbert dziękował Haluni za otrzymaną książkę: „No i ten Liebert. Kochanie - bez fałszywej skromności - nie możesz, naprawdę nie możesz pozbywać się dla mnie ukochanego poety". Kilka zdań dalej dodawał: „Od paru lat myślę o wierszu, który miałby tytuł List do Jerzego Lieberta. Jeśli się kiedyś to urodzi będzie to list także do Ciebie" 35 . Pomysł utknął w fazie prenatalnej - w materiałach archiwalnych zachował się nieukończony szkic utworu o takim tytule. Wcześniej powstał jednak cykl erotyków.

Otwiera go wiersz Piosenka o nas, w którym ponowiony został, podjęty już w lirykach z części pierwszej, problem głównej i jakże prozaicznej przeszkody utrudniającej parze zakochanych osiągnięcie bliskości, intymności, prywatności - brak mieszkania: "Całujemy się na skwerze / bo nie mamy swego domu”, i kilka strof dalej: „Właśnie w tym jest cały dramat / że nie mamy swego domu" [UR, s. 47]. Temat może się wydawać mało poetycki, ale kłopoty mieszkaniowe, w Polsce lat 50. powszechne, stanowiły istotną perypetię $\mathrm{w}$ „historii niedokończonej miłości”. Zresztą nawiąże do tego poeta także w słuchowisku Drugi pokój, które Jacek Kopciński słusznie nazwał „dramatem kwaterunkowym” ${ }^{36}$. Para ludzi w powojennej rzeczywistości marząca o własnym mieszkaniu to nie tylko realny problem emo-

\footnotetext{
34 W oryginale: „Ramieniem ciebie garnę, skrzydłem dotykam nieba / A Ty nie jesteś niebem, wiem o tym i tak trzeba" [J. Liebert, Pisma zebrane 1. Poezja - proza, zebrał, oprac. i wstępem opatrzył. S. Frankiewicz, Warszawa 1976, s. 248].

35 Z. Herbert, Listy do Muzy. Prawdziwa historia nieskończonej miłości, oprac. M. Marchlewska, Gdynia 2000, s. 13.

36 J. Kopciński, Nasłuchiwanie. Sztuki na głosy Zbigniewa Herberta, Warszawa 2008, s. 285.
} 
cjonalno-społeczny, ale także kolejny motyw Staffowski ze znanego wiersza Pierwsza przechadzka, pochodzącego z wydanego w 1946 roku tomu Martwa pogoda. Różnica dotyczy nastrojowej tonacji. O ile Staff przewiduje z nadzieją: „Będziemy mieszkać znowu w swoim domu” ${ }^{37}$, o tyle Herbert zdaje się być zrezygnowany: „nie mamy swego domu”. Podobne jest natomiast poszukiwanie intymnej enklawy: $w$ miejskich, oddalonych od ruin przedmieściach (Pierwsza przechadzka) i w leśnej okolicy, która okazuje się wcale nie taka ustronna (Piosenka o nas):

Przykucamy w małym lasku skąd nas płoszy stuk dzięcioła szmer leszczyny podejrzany i leśniczy niedyskretny

[UR, s. 47]

Kolejnych sześć wierszy tworzy mini-cykl, którego tematykę określa tytuł pierwszego z tych liryków - Spacer po lesie. Przechadzka zakochanych nie stała się jednak pretekstem do miłosnych wyznań, poeta występuje tu bardziej w roli obserwatora fauny i flory. Skupia swoją uwagę na drzewach, kwiatkach, ptaszkach, słowikach, mrówkach, żuczkach. Co prawda deminutywy wprowadzają nastrój sentymentalno-idylliczny, bardziej chodzi tu jednak o pewną postawę filozoficzno-estetyczną, którą później będzie się kierował Homer (jako porte parole Herberta) w dramacie Rekonstrukcja poety "zachwalam mały palec, tamaryszek, kamyki" ${ }^{38}$. Na zainteresowanie poezji lirycznej zasługuje to, co delikatne, drobne, bezbronne, zwyczajne i wzbudzające czułość.

W tych sześciu wierszach dają się słyszeć zarazem echa ówczesnych lektur Herberta. Utwór Słowiki powołuje się chociażby na "słowa znad obcego jeziora / o dwu smutnych słowikach co wabią się płaczem”, czyli na wiersz Słowackiego Rozłaczenie napisany nad jeziorem Leman ${ }^{39}$. Istotniejsze wydają się jednak kolejne dowody pisania „pod Staffa”. U autora Wysokich drzew pojawiała się zarówno tematyka leśna (np. Jesień w lesie, Cisza leśna), jak i „ornitologiczna” (np. Przeczucie skowronka, Zatarg z ptakami, Do wróbla). Znalazłyby się też przesłanki potwierdzające tezę pisania "pod Lieberta”.

\footnotetext{
37 L. Staff, Wiersze zebrane, t. 5, red. M. Szypowska, Warszawa 1955, s. 290.

38 Z. Herbert, Dramaty, oprac. J. Kopciński, Warszawa 2008, s. 100.

39 Chodzi głównie o następujący fragment: „A ty - wiecznie zagasłaś nad biednym tułaczem; / Lecz choć się nigdy, nigdzie połączyć nie mamy, / Zamilkniemy na chwilę i znów się wołamy / Jak dwa smutne słowiki, co się wabią płaczem" [J. Słowacki, Wiersze i poematy, Warszawa 1981, s. 26].
} 
Zaglądnijmy chociażby do wiersza Zachęta do ucieczki poetycko rezonującego z mini-cyklem Herberta:

Ciche są gąszcze i polanki, na prawo różowe błękity.

Serdeczniejsze od ludzkich rąk są drzew gałęzie,

Gdzie ptak srebrem wypryska i więźnie,

I jesionów ukochanych stalagmity ${ }^{40}$.

Irena Sławińska, pozwalając sobie na lekką ironię, zauważała, że Liebert tworzył dość obiegowe i poetycko konwencjonalne „erotyki z lilią, różą i motylem" ${ }^{41}$. Herbert, relacjonując historię „leśnej miłości” (określenie z wiersza Kwiatek), też nie silił się specjalnie na oryginalność. Wystrzega się jednak sentymentalnej naiwności. Przyglądając się tym wszystkim okazom leśnej fauny i flory, dostrzega - co raczej nietypowe w erotykach - manichejskie cienie czające się w życiu przyrody: „Po co żyją mrówki? Ja myślę, że po to / by zabijać jaszczurki, gdy zbłądzą czasem / by szeleścić w podszyciu" [UR, s. 52]. Wybrzmiewa w tych refleksjach zapowiedź późniejszych "ciemnych pytań", które poeta będzie stawiał chociażby w wierszu Dęby.

Drugą część Podwójnego oddechu domykają cztery utwory poetyckie, zarysowujące kolejne detale na "mapie uczucia” (posługuję się trafnym określeniem Andrzeja Franaszka ${ }^{42}$ ). Niezależnie od oceny artystycznego poziomu tych wierszy daje się $\mathrm{w}$ nich dostrzec dążenie do pogodzenia ze sobą $\mathrm{z}$ jednej strony ujawnianych spontanicznie i bezpośrednio emocji, a z drugiej trochę już wyświechtanej konwencji poezji erotycznej, choćby tej reprezentowanej przez Lieberta. "Jakie słowo wyraża rozłąkę i bliskość, wyciągnięte ręce i Twój wzrok, który czuję na sobie"? - powtórzmy to pytanie poety z dedykacji do "Najmilszej”. Nic nie daje się bowiem tak łatwo sprowadzić w poezji do banału jak wezbrane uczucia. Jeszcze inaczej: „Tym, co hamuje miłosny zapis, jest złudzenie wyrażalności" - pouczał Barthes ${ }^{43}$. Dyskurs miłosny Herberta opiera się przede wszystkim na próbie zapisu obopólnej gry doznań zmysłowych: „Tak bardzo chciałbym w pejzaż ów / jak w bursztyn Ciebie miła zakląć" [Patrz morze - UR, s. 55], „a wieczorem Twoim oczom / zawierzam cały mój niepokój” [Piosenka zakochanego - UR, s. 56], „Do tej gwiazdy razem dążyć razem patrzeć" [Astronomia - UR, s. 57], "Cicha rozmowa dwu oddechów / mocno splecionych w jasny warkocz" [Podwójny oddech - UR, s. 58].

\footnotetext{
40 J. Liebert, Pisma zebrane, s. 124.

41 I. Sławińska, Groza słowa, "Znak” 1949, nr 2, s. 124.

42 A. Franaszek, Herbert. Biografia I. Niepokój, Kraków 2018, s. 337.

43 R. Barthes, Fragmenty dyskursu miłosnego, s. 150.
} 


\section{„Wypowiedzieć miłość”}

Miłość wyraża się, zgodnie z tradycyjną konwencją literacką, w spojrzeniu, zapatrzeniu, spotkaniu oczu, ale także w bardziej cielesnym, materialnym i "konkretnym” dotyku. W wierszu Podwójny oddech istotę Herbertowego erotyzmu haptycznego oddaje znakomicie fraza "ślepych dłoni pożądanie" [UR, s. 58]. W opublikowanym później, znanym utworze Dotyk o tytułowym zmyśle poeta wyrazi się jeszcze bardziej jednoznacznie i uroczyście: „o najprawdziwszy ty jedynie / potrafisz wypowiedzieć miłość” ${ }^{44}$. Dotyk jest językiem erotycznego porozumienia. Na tego rodzaju skojarzenia nakierowuje także motto zaczerpnięte z wiersza Paula Eluarda Powiedziałem ci to, otwierające trzecią cześć cyklu: „Wszelka pieszczota wszelka ufność przetrwają siebie" [UR, s. 59].

W całym cyklu Podwójny oddech sięga poeta po topikę miłosną eksploatującą dwa komplementarne względem siebie i wcześniej już zasygnalizowane w liryku Czułość motywy oczu i dłoni. Znakomitą tego ilustrację stanowią trzy wiersze rozpoczynające trzecią część cyklu. Dwa pierwsze z nich świadczą o tym, że Herbert relację miłosną traktował jak szkołę poznania zmysłowego. W utworze Nauczyłaś mnie patrzeć ukochana kobieta występuje $\mathrm{w}$ roli nauczycielki, która edukuje poetę $\mathrm{w}$ umiejętności zaglądania pod "skórę przedmiotów", do wnętrza obłoku, róży i do wnętrza kobiecości. Możliwe zresztą, że preceptorem był tutaj bardziej Rilke, u którego "spojrzenie zwrócone do wnętrza" stanowiło ważny imperatyw poetyckiego światopoglądu ${ }^{45}$. Wiersz $\mathrm{Na}$ pamięć ujawnia z kolei taktylny charakter doświadczenia erotycznego:

Nauczyć się Ciebie na pamięć
a potem
być dobrym ojcem
Twoich kształtów

[UR, s. 63]

Współwystępowanie różnych wrażeń zmysłowych niekoniecznie prowadzi do efektu synergii. Poeta zwraca uwagę na warunek "czystego", niezakłóconego poznania dotykowego - należy „[z]amknąć oczy / wyrzec się świata / by zdobyć znikomy ruch" (UR 63). Inaczej przedstawia się współ-

44 Z. Herbert, Wiersze zebrane, s. 85.

45 Zob.: A. Melberg, Spojrzenie zwrócone ku wnętrzu, „Poznańskie Studia Polonistyczne. Seria Literacka" 2011, nr 18, s. 191-210. 
praca ze słuchem. Przywołajmy wiersz Erotyk, który co prawda nie pochodzi $\mathrm{z}$ omawianego cyklu, ale prezentuje samą istotę erotyzmu haptycznego:

Ty jesteś ze skóry i ciepła

Gdy leżysz pode mną jak klawisz

Klawisz jest biały i niemy

Dotykiem trzeba go rozgrzać

Wtedy staje się bledszy

I zmienia się $\mathrm{w}$ melodię

Która przenika i spełnia

[UR, s. 14]

Obraz kobiety przyrównanej do muzycznego instrumentu został już wcześniej przywołany w wierszu Na pamięć. Sytuacje opisywane przez Herberta dotyczą często reakcji poszczególnych zmysłów i receptywnych części ciała na obecność bądź nieobecność ukochanej. Tak jest w kolejnym wierszu z cyklu Ręce i oczy. Mężczyzna czeka na kobietę w znanych już nam okolicznościach - wieczorem pod rozgwieżdżonym niebem, „w świetle księżyca”. I wyznaje, że "z tęsknoty” - „Ręce moje szukają / oczy popłyną do światła" [UR, s. 65]. Ten wiersz, jak i dwa kolejne, rozgrywa się w scenerii kolejowego peronu, miejsca oczekiwań i rozstań: „ręce długie jak szyny / na księżycowym torze / samotny cygański wagon" [Ręce i oczy - UR, s. 65], "cień mój na peronie / kiedy pociąg odjeżdża” [Opuszczony - UR, s. 66], "odjazdy palą w gardle" [Daleko - UR, s. 67]. Pragnienie zmysłowej bliskości i fizyczne oddalenie - to najczęstsza sytuacja w erotykach Herberta.

Motyw oczu i rąk odnajdujemy także w dwóch wierszach charakteryzujących parę kochanków: „Oczy miała okrągłe / dobre i stale otwarte / [...] / jeszcze ręce / drobne jak deszcz / i bezbronne od pieszczot" [Ona-UR, s. 69], „Śpię [...] / pod oczu Twych zieloną rzęsą" [Ja - UR, s. 71]. Erotyczna zmysłowość przejawia się w spojrzeniu i dotyku. Ale nie tylko. Do doznań miłosnych zalicza poeta także "mały strumyczek dwu oddechów" [Podwójny oddech - UR, s. 58]. Nieprzypadkowo chyba zjednoczenie dotyczy tego, co niematerialne i ulotne. W Piosence o zamieraniu oddech staje się ostatecznym i docelowym stanem miłości jakby uduchowionej, ale także bezcielesnej, pozbawionej zmysłowego spełnienia:

To $\mathrm{z}$ tęsknoty to $\mathrm{z}$ wyrzeczenia

coraz bliżsi i bliżsi

chwili co zmieni nas

$\mathrm{w}$ tchnienie

[UR, s. 72] 
Wyrzeczenia i niespełnienia, $\mathrm{w}$ innym nieco znaczeniu, dotyczy także kolejny, elegijny w tonacji wiersz Nie mam komu. Poeta układa w nim kołysankę dla nienarodzonego dziecka, poczętego raczej tylko w wyobraźni: „To już koniec / śpij mój mały / urojony” [UR, s. 73]. Herbert po latach, w wieku 44 lat, zdecydował się na zawarcie związku małżeńskiego $\mathrm{z}$ inną kobietą, nigdy jednak nie został ojcem.

Cały cykl erotyków domyka wiersz Nasza miłość. W epilogu poeta ujawnia dramatyzm i fatalizm tej raczej „niedokończonej” niż „nieskończonej miłości". Utwór składa się z dwóch numerowanych części, w pierwszej postawiona zostaje złowieszcza diagnoza, w drugiej - narzucona terapia szokowa. Zgodnie z diagnozą miłość nie wiedzie do wspólnego szczęścia; jest co prawda jak „[p]łomień który oczyszcza” i „który przepala” [UR, s. 75], ale z powodu rozłąki i przestrzennego oddalenia kochanków uniemożliwia erotyczną intymność, powoduje wyjałowienie doznań zmysłowych: „ręka która oddala / usta dalekie i zimne”, "ręka która usycha / usta sinieją bez pieszczot" [UR, s. 75]. Poeta znajduje się w stanie twórczego impasu - nie może swojej ukochanej opisać, mówić do niej, milczeć, śmiać się, płakać przy niej, ani na nią patrzeć. Pozbawiony przeżyć sensualnych nie potrafi „wypowiedzieć miłości". W tej sytuacji decyduje się na drastyczną terapię (albo zręczny wybieg) - „Oto pora wyrzeczeń" [UR, s. 75]. Egzorcyzmy dotyczą marzeń, wspomnień, nadziei. Filozofia wyrzeczenia, tak to przynajmniej przedstawia Herbert, prowadzi do mistycznego oczyszczenia: „Nic mi nie pozostaje / tylko miłość". Miejsce zmysłowego Erosa ma zająć duchowa Agape:

Nasza miłość wyzwolona od pieszczot nasza miłość wysoka i gorzka

bliższa gwiazd niźli bicia serca

nasza miłość poświęcona Bogu

[UR, s. 76]

Pomysł, aby własne perypetie miłosne (a zachowywał się dość niejednoznacznie) interpretować na sposób religijny i mistyczny, mógł Herbert zaczerpnąć chociażby z pism św. Augustyna. Nieodparcie nasuwa się jednak przypuszczenie, że swój związek uczuciowy z Halą chciał poeta postrzegać przez analogię do relacji łączącej Lieberta z Agnieszką, czyli Bronisławą Wajngold. Skończyło się na deklaracjach. „Jeszcze raz - zwierzał się ukochanej - robię ścisły i zimny rachunek sumienia i wyznaję, że moim największym grzechem było to, że nie potrafiłem ukryć mojej miłości, a wyjawiwszy ją nie potrafiłem nasz stosunek uczynić bardziej duchowym" ${ }^{46}$.

46 Z. Herbert, List do Muzy, s. 6. 
Cykl Podwójny oddech powstawał w okresie, gdy Herbert po wielu latach intelektualnych i artystycznych poszukiwań, odnalazł własną poetycką dykcję. Erotyki zaadresowane do „Dalekiej i Czystej” Hali były próbą „wypowiedzenia miłości". Sam poeta ocenił, że ten zamiar nie bardzo mu się powiódł: „To są chyba kiepskie wiersze, gdyż nigdy nie mogłem opanować wzruszenia, kiedy pisałem" [UR, s. 37]. Może jednak nie aż tak kiepskie, bo odnajdujemy w nich wiele sugestywnych, zapadających $w$ pamięć fraz i obrazów. Znamienne jednak, że w późniejszej opublikowanej twórczości Herberta tak bezpośrednie i szczere erotyki praktycznie już się nie pojawiają. Poezja, w której zagości Pan Cogito, będzie co prawda wyczulona na wszelkie doznania zmysłowe, ale zarazem będzie się kierować zasadą opanowywania wzruszeń. Postawa emocjonalnego dystansu zaznacza się nawet w takich noszących znamiona erotyków wierszach, jak Różowe ucho, Alienacje Pana Cogito czy Jedwab duszy.

Redaktorskie uporządkowanie Podwójnego oddechu umożliwia rozpoznanie kompozycyjnego układu całego cyklu - tytuł, dedykacja, przedmowa, motta i trzy wyodrębnione, ale też powiązane ze sobą części. Bardziej oczywiste stają się literackie nawiązania. $\mathrm{W}$ dyskursie miłosnym Herberta występują obok siebie: pragnienie bliskości i doświadczenie rozłąki, samotność i czułość, spojrzenie oczu i dotyk rąk, przeżycia sensualne i symboliczne sublimacje. W ocenie samego autora jest to jednak „pamiętnik niedokończonej miłości”. Listy do „wyrozumiałej Eurydyki” 47 dostarczają wyjaśnień. Przede wszystkim nie powiodła się próba przeobrażenia zmysłowego Erosa w duchowe Agape, a ,ja" poety, nade wszystko ceniące sobie artystyczną niezależność, ostatecznie wyrzekło się "my” dwojga ludzi decydujących się na wspólny los. Miłość bez erotyzmu okazała się niemożliwa, tak w poezji, jak i w życiu.

\section{Bibliografia}

Antoniuk Mateusz (2009), Otwieranie głosu. Studium o wczesnej twórczości Zbigniewa Herberta (do 1957 roku), Kraków: Wydawnictwo Platan.

Augustyn św. (1987), Wyznania, przeł., opatrzył posłowiem i kalendarium Z. Kubiak, Warszawa: Pax.

Baczyński Krzysztof Kamil (1970), Utwory zebrane, t. I, oprac. A. Kmita-Piorunowa, K. Wyka, Kraków: Wydawnictwo Literackie.

47 Tamże, s. 16. 
Barthes Roland (1999), Fragmenty dyskursu miłosnego, przekład i posłowie M. Bieńczyk, wstęp M.P. Markowski, Warszawa: KR.

Fert Józef (2000), Hala Pana Cogito czyli wszystko na sprzedaż, „Ethos”, nr 4, s. 163-171. Franaszek Andrzej (2018), Herbert. Biografia I. Niepokój, Kraków: Społeczny Instytut Wydawniczy Znak.

Herbert Zbigniew (2008), Dramaty, oprac. J. Kopciński, Warszawa: Towarzystwo „Więź".

Herbert Zbigniew (2008), Król mrówek. Prywatna mitologia, oprac. R. Krynicki, Kraków: Wydawnictwo a5.

Herbert Zbigniew (2000), Listy do Muzy. Prawdziwa historia nieskończonej miłości, oprac. M. Marchlewska, Gdynia: Małgorzata Marchlewska Wydawnictwo.

Herbert Zbigniew (2010), Utwory rozproszone: (rekonesans), wybór i oprac. edytorskie R. Krynicki, Kraków: Wydawnictwo a5.

Herbert Zbigniew (2001), Węzeł gordyjski oraz inne pisma rozproszone 1948-1998, zebrał i oprac. P. Kądziela, Warszawa: Biblioteka "Więzi".

Herbert Zbigniew (2011), Wiersze zebrane, oprac. edytorskie R. Krynicki, Kraków: Wydawnictwo a5.

Herbert Zbigniew, Chrzanowski Tadeusz (2016), „Mój bliźni, mój bracie”. Zbigniew Herbert - Tadeusz Chrzanowski: listy 1950-1998, oprac. Z. Baran, Kraków: Społeczny Instytut Wydawniczy Znak.

Herbert Zbigniew, Elzenberg Henryk (2002), Korespondencja, oprac. B. Toruńczyk, Warszawa: Fundacja Zeszytów Literackich.

Herbert Zbigniew, Turowicz Jerzy (2005), Korespondencja, oprac. T. Fiałkowski, Kraków: Wydawnictwo a5.

Herbert Zbigniew, Zawieyski Jerzy (2002), Korespondencja 1949-1967, oprac. P. Kądziela, Warszawa: Biblioteka "Więzi".

Jasińska-Wojtkowska Maria (1983), Sacrum w poezji Leopolda Staffa, w: Religijne tradycje literatury polskiej, t. 1: Polska liryka religijna, red. S. Sawicki, P. Nowaczyński, Lublin: Wydawnictwo Towarzystwa Naukowego KUL, s. 371-422.

Kopciński Jacek (2008), Nasłuchiwanie. Sztuki na głosy Zbigniewa Herberta, Warszawa: Towarzystwo „Więzi".

Lam Andrzej (2001), Zbigniew Herbert przed debiutem ksią̇kowym, w: Twórczość Zbigniewa Herberta, red. M. Woźniak-Łabieniec, J. Wiśniewski, Kraków: Universitas, s. 11-26.

Liebert Jerzy (1976), Pisma zebrane 1. Poezja - proza, zebrał, oprac. i wstępem opatrzył S. Frankiewicz, Warszawa: Biblioteka „Więzi”.

Melberg Arne (2011), Spojrzenie zwrócone ku wnętrzu, „Poznańskie Studia Polonistyczne. Seria Literacka", nr 18, s. 191-210.

Rilke Rainer Maria (1987), Poezje, wybrał, przeł. i posłowiem opatrzył M. Jastrun, Kraków: Wydawnictwo Literackie.

Siedlecka Joanna (2002), Pan od poezji. O Zbigniewie Herbercie, Warszawa: Prószyński i S-ka.

Sławińska Irena (1949), Groza słowa, "Znak”, nr 2, s. 118-133.

Słowacki Juliusz (1981), Wiersze i poematy, Warszawa: Państwowy Instytut Wydawniczy. 
Staff Leopold (1955), Wiersze zebrane, t. 1, red. M. Szypowska, Warszawa: Państwowy Instytut Wydawniczy.

Staff Leopold (1955), Wiersze zebrane, t. 2, red. M. Szypowska, Warszawa, Państwowy Instytut Wydawniczy.

Staff Leopold (1955), Wiersze zebrane, t. 5, red. M. Szypowska, Warszawa: Państwowy Instytut Wydawniczy.

\section{"About love, without eroticism". Philological reading of Zbigniew Herbert's Podwójny oddech Summary}

The article is a proposal for a new interpretation of Herbert's erotic poems from a collection entitled Podwójny oddech [Double Breath], whose illegal publication caused confusion among readers and literary scholars. In addition to legal matters, the discussion also concerned the artistic level of this collection of poetry. The author draws attention firstly - to the conscious compositional idea in the Podwójny oddech, secondly - to a series of intertextual references that testify to the poet's reading, thirdly - to the poet's attempt to find the proper poetic language to express the love experiences and fourthly - to a specific, shaped by religious schemes, philosophy of love.

Keywords: Polish poetry, eroticism, epistolography, poetics, intertextuality 